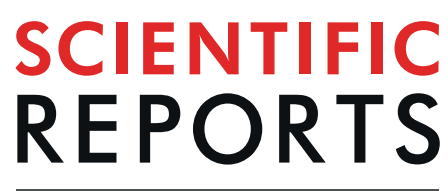

natureresearch

Received: 21 August 2018

Accepted: 15 July 2019

Published online: 06 August 2019

\section{Low-temperature catalyst based Hydrothermal liquefaction of harmful Macroalgal blooms, and aqueous phase nutrient recycling by microalgae}

Vinod Kumar ${ }^{1}{ }^{1}$, Sanjay Kumar ${ }^{2}{ }^{2}$, P. K. Chauhan ${ }^{3}$, Monu Verma $^{4}$, Vivekanand Bahuguna ${ }^{5}$, Harish Chandra Joshi ${ }^{1}$, Waseem Ahmad ${ }^{1}$, Poonam Negi ${ }^{1}$, Nishesh Sharma ${ }^{5}$, Bharti Ramola ${ }^{1}$, Indra Rautela ${ }^{5}$, Manisha Nanda ${ }^{6} \&$ Mikhail S. Vlaskin ${ }^{7}$

The present study investigates the hydrothermal liquefaction (HTL) of harmful green macroalgal blooms at a temperature of $270^{\circ} \mathrm{C}$ with, and without a catalyst with a holding time of $45 \mathrm{~min}$. The effect of different catalysts on the HTL product yield was also studied. Two separation methods were used for recovering the biocrude oil yield from the solid phase. On comparision with other catalyst, $\mathrm{Na}_{2} \mathrm{CO}_{3}$ was found to produce higher yiled of bio-oil. The total bio-oil yield was $20.10 \%$ with $\mathrm{Na}_{2} \mathrm{CO}_{3}, 18.74 \%$ with $\mathrm{TiO}_{2}, 17.37 \%$ with $\mathrm{CaO}$, and $14.6 \%$ without a catalyst. The aqueous phase was analyzed for TOC, $\mathrm{COD}$, TN, and TP to determine the nutrient enrichment of water phase for microalgae cultivation. Growth of four microalgae strains viz., Chlorella Minutissima, Chlorella sorokiniana UUIND6, Chlorella singularis UUIND5 and Scenedesmus abundans in the aqueous phase were studied, and compared with a standard growth medium. The results indicate that harmful macroalgal blooms are a suitable feedstock for HTL, and its aqueous phase offers a promising nutrient source for microalgae.

The appearance of a dense mat of macroalgae on water bodies is a widespread phenomenon. An algal bloom is a result of accumulating algal biomass in the slow-moving lake, pond or river. Macroalgae blooms are largely filamentous, unattached forms, and are mainly green algal species found in nutrient-rich, and temperate waters. Increase of nitrogen and other micropollutants into water bodies are linked to increases in macroalgal blooms worldwide ${ }^{1}$.

Accumulation of macroalgae in rivers and ponds leads to microbial decomposition that may reduce dissolved oxygen in the water bodies due to algal respiration ${ }^{2}$. Low dissolved oxygen content in water bodies leads to a change in biodiversity and species composition ${ }^{3}$. Macroalgal blooms lead to a decline in the growth of non-blooming algae and also affects the diversity of plankton and zooplankton in water bodies ${ }^{4}$. These algal blooms affect the ecosystem by changing the quality of water, light penetration, and alteration of the food chain, and food $\mathrm{web}^{5}$. Various initiatives have been undertaken to deracinate the problem related to algal blooms contaminate freshwater as well as marine water ${ }^{5}$. Many studies have been reported on producing biofuels from microalgae ${ }^{6}$. However, a limited number of studies are related to the use of macroalgae for biofuel production. Toxic algal blooms can be used as a cheap raw material for microalgae cultivation because its density has extensively increased worldwide in recent years due to wastewater being discharged into water bodies ${ }^{7}$.

${ }^{1}$ Department of Chemistry, Uttaranchal University, Dehradun, 248007, India. ${ }^{2}$ Department of Life Sciences, Food Technology, Graphic Era Deemed to be University, Dehradun, 248001, India. ${ }^{3}$ Faculty of Applied Sciences and Biotechnology, Shoolini University, Solan, HP, India. ${ }^{4}$ Department of Chemistry, Amity School of Applied Sciences (ASAS), Amity University Haryana, Gurugram-122413, Haryana, India. ${ }^{5}$ Department of Biotechnology, Uttaranchal University, Dehradun, 248007, India. ${ }^{6}$ Department of Biotechnology, Dolphin (PG) Institute of Biomedical and Natural Sciences, Dehradun, 248007, India. ${ }^{7}$ Joint Institute for High Temperatures of the Russian Academy of Sciences, 13/2 Izhorskaya St, Moscow, 125412, Russia. Correspondence and requests for materials should be addressed to V.K. (email: vinodkdhatwalia@gmail.com) or M.N. (email: Manisha1083@gmail.com) 
Hydrothermal liquefaction (HTL) is a process in which wet algal feedstocks at $200-400{ }^{\circ} \mathrm{C}$ temperature and 10-15 MPa pressure gets converted into four products (1) Bio-crude oil (2) Gas (3) Solid phase and (4) Aqueous phase rich in organics and nutrients ${ }^{8}$. During the HTL process, along with lipids, proteins and carbohydrates also get converted into biocrude oil. Therefore, the yield of oil is higher using HTL ${ }^{8,9}$. Thus, HTL is well suited to a variety of biomass, including bacteria, wastewater sludge, and algal biomass, which is fast-growing but have low-lipid contents. This process provides the energetic advantages by the use of wet algal biomass and the efficient separation of products over alternative techniques such as lipid isolation and transesterification, pyrolysis etc ${ }^{9}$. HTL is ideal for conversion of high-moisture biomass into biocrude oil because water acts as a reaction medium and thus avoids the costly phase of biomass drying?.

The use of a catalyst was found more to be suitable for HTL of macroalgae as compared to microalgae because it increases the conversion of carbohydrates into biocrude oil ${ }^{10}$. Previous studies have shown that most of the catalysts lead to a significant increase in biocrude oil. HTL process will not be economically viable if these catalysts cannot be recycled properly ${ }^{11,12}$. $\mathrm{Na}_{2} \mathrm{CO}_{3}$ increases the HTL biocrude oil yield of terrestrial plants, and microalgae by promoting hydrolysis ${ }^{12}$.

Quality of the biocrude oil is dependent on the properties of the algal biomass. High carbon, hydrogen content and low ash, nitrogen, sulfur, and oxygen content containing biomass are considered as ideal for HTL ${ }^{13}$. HTL bio-crude ids dark in color, highly viscous liquid which is $10-10,000$ times higher than that of conventional fuel and have a smoke-like smell ${ }^{14}$. High nitrogen content of algal biomass results in higher nitrogen content in HTL biocrude oil. This causes emission of toxic NOx which can be removed by the refining process. The high carbon content of algal biomass resulted in high biocrude yield by HTL process ${ }^{10}$. Composition of biocrude oil is mainly carbon content (71-73\%), hydrogen content (7-8\%), oxygen content (10-11\%), nitrogen content (6-7\%) and sulfur content $(0-1 \%)$ which leads to less greenhouse gas emissions as compared to conventional biofuel and bioeth$\mathrm{anol}^{10}$. Biocrude can be upgraded for the production of gasoline, jet fuel, and other fuel by using a suitable catalyst which can remove oxygen, nitrogen and double bonds ${ }^{15}$. However, HTL shows a negative energy balance, which is the principal disadvantage of this process. Fast heating and cooling also increase the yield of biocrude oil because of better conversion of protein, lipid, and carbohydrates into liquid fuel rather than solid or gaseous fuel ${ }^{10}$.

According to the energy-efficiency ratio, the use of HTL aqueous phase for microalgae cultivation shows a positive energy balance for biofuel production ${ }^{16}$. Recycling nutrients from wastewater could potentially fulfil the nutrients requirement for microalgae cultivation and scope to integrate the biofuel production and wastewater treatment ${ }^{17}$. Post-hydrothermal liquefaction aqueous phase can accumulate approximately $80 \%$ of nutrients and some organics, this provides an excellent opportunity for nutrient and carbon recycling ${ }^{8}$. The nutrients and carbon recycling have been investigated in some recent studies using aqueous phase of HTL ${ }^{18}$. These studies show that nutrients and carbon in the aqueous phase from hydrothermal liquefaction can be used for microalgae cultivation at different dilution factors (50-500 times $)^{19}$. Several studies have been reported in the literature on nutrient cycling of HTL wastewater for microalgae cultivation, but the effect of a different catalyst on the growth of microalgae has not been reported yet. In a study, Jain et al. ${ }^{7}$ reported that freshwater toxic algal blooms are a promising feedstock for microalgae cultivation.

The present study investigates explicitly a novel integrated method of using harmful algal blooms as biomass for energy production that synergistically combines algal blooms biofuel production using the HTL process as given in Fig. 1. This study aims to experimentally confirm the feasibility of the harmful green algal blooms for biocrude production completed in four steps. Four steps includes (1) utilization of harmful macroalgal blooms for the HTL process. (2) Increase the yield of biocrude oil using different separation methods. (3) Study the effect of different catalysts on biocrude oil yield. (4) Use of aqueous phase of HTL processes with a catalyst for the cultivation of microalgae.

\section{Results}

Analysis of macroalgal blooms. The proximate analyses of macroalgal blooms (Supplementary Figs 1-3) are respectively listed in Table 1, 87.23\% moisture, $62.01 \%$ volatile substantial, $19.02 \%$ ash content and $31.19 \%$ C, $8.42 \% \mathrm{H}, 4.22 \% \mathrm{~N}$ and $54.61 \%$ O. FTIR spectrum reflects (Supplementary Fig. 4) three central regions, lipid band (around $\left.1630 \mathrm{~cm}^{-1}\right)$, amide band $\left(1401 \mathrm{~cm}^{-1}\right)$ and the carbohydrate region $\left(1100-874 \mathrm{~cm}^{-1}\right)$.

Product yields by HTL. In this study yields of bio-crude oil by the two separation methods were investigated. In the first separation method (without soxhlet), $10.03 \%$ of biocrude oil was obtained. The results indicated that oil yield was high (14.06\%) in second separation method (with soxhlet). The Soxhlet extraction method was selected and then further evaluated for their bio-crude oil yield with different catalysts for $45 \mathrm{~min}$ at $270{ }^{\circ} \mathrm{C}$ as given in Fig. 1. The total bio-oil was $20.10 \%$ with $\mathrm{Na}_{2} \mathrm{CO}_{3}, 18.74 \%$ with $\mathrm{TiO}_{2}, 17.37 \%$ with $\mathrm{CaO}$, and $14.6 \%$ without a catalyst. The biochar yield was $30.12 \%, 30.05 \%, 32.09 \%$ and $35.84 \%$ for $\mathrm{Na}_{2} \mathrm{CO}_{3}, \mathrm{TiO}_{2}, \mathrm{CaO}$, and without catalyst respectively. The total biocrude oil yield was measured by the mixing of bio-oil-1 and bio-oil- 2 . The significant portion of biocrude oil one was obtained from the acetone extraction of the solid phase.

Analysis of the biocrude oil obtained by HTL. The biocrude oil obtained from the macroalgal blooms have been analyzed by Gas Chromatography (GC), and NIST library was used for the identification of compounds (Table 2). Nine main compounds were identified based on retention area $\%>1$ during direct HTL without catalysts at $270^{\circ} \mathrm{C}$ and $45 \mathrm{~min}$ of reaction time. The compounds such as amides derivatives, palmitic acid, phenolic compounds, and ketones derivatives, alkanes and alkenes derivatives and some furans were considered as central components of biocrude oil obtained by HTL of algal biomass ${ }^{20}$. Most of the components identified in biocrude oil extracted using macroalgal blooms were somewhat similar to those obtained from microalgae. However, differences in some of the compounds (Pyrrolo [1,2-a]pyrazine-1,4-dione hexahydro-3-(2-methylpropyl and 


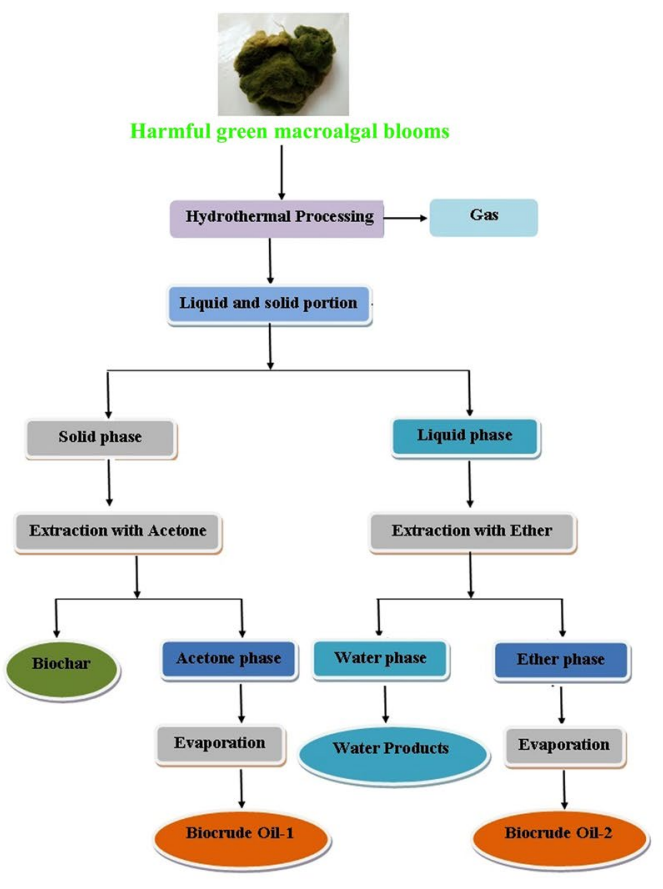

A

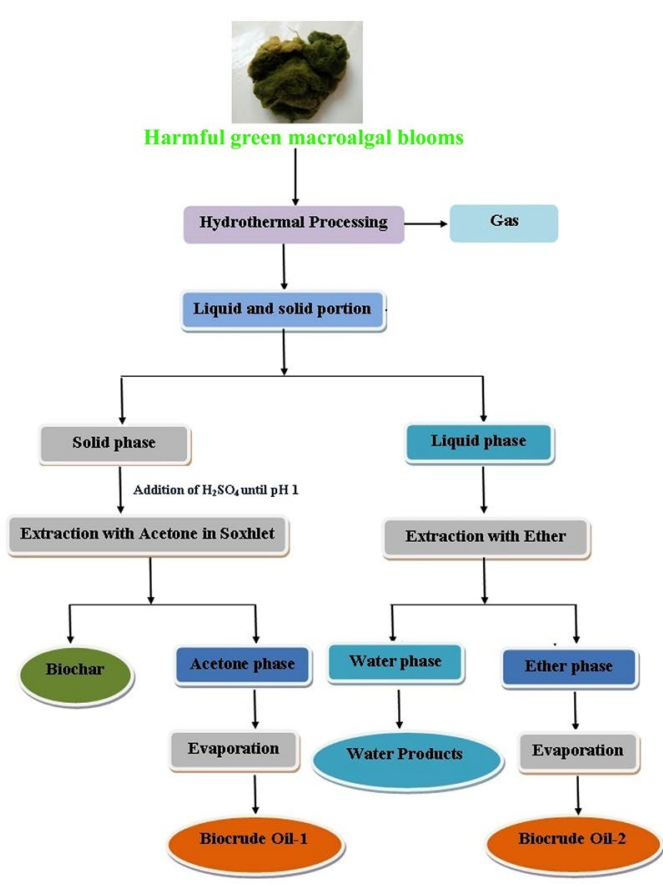

B

Figure 1. (A) Simple separation and extraction procedure. (B) Soxhlet based separation and extraction procedure.

\begin{tabular}{|l|l|}
\hline \multicolumn{2}{|l|}{ Proximate analysis \% } \\
\hline Moisture (wet biomass) & $87.23 \pm 0.1$ \\
\hline Volatile solid & $62.01 \pm 0.2$ \\
\hline Ash & $19.02 \pm 0.1$ \\
\hline Elemental analysis \% & $31.19 \pm 0.3$ \\
\hline C & $8.42 \pm 0.1$ \\
\hline H & $4.22 \pm 0.2$ \\
\hline N & $54.61 \pm 0.2$ \\
\hline O & $1.56 \pm 0.1$ \\
\hline S & $9.45 \pm 0.3 \mathrm{MJ} \mathrm{kg}^{-1}$ \\
\hline HHV &
\end{tabular}

Table 1. Proximate analysis of harmful algal blooms.

\begin{tabular}{|l|c|}
\hline Compounds identified in bio-oil & Area $\%$ \\
\hline 3-Penten-2-one, 4-methyl & 6.88 \\
\hline 2-Pentanone, 3-methylene & 5.94 \\
\hline 2-Pentadecanone, 6,10,14-trimethyl & 16.38 \\
\hline n-Hexadecanoic acid & 18.70 \\
\hline Pentadecanoic acid & 23.81 \\
\hline Phytol & 8.2 \\
\hline Tetradecanoic acid & 6.1 \\
\hline Pyrrolo[1,2-a]pyrazine-1,4-dione hexahydro-3-(2-methylpropyl) & 4.91 \\
\hline Phenol & 3.22 \\
\hline
\end{tabular}

Table 2. GC-MS analysis of bio-oil extracted from harmful green macroalgal blooms at $270^{\circ} \mathrm{C}$. 


\begin{tabular}{|l|l|l|l|l|l|l|l|l|l|}
\hline Reaction & $\begin{array}{l}\text { Biocrude oil } \\
\text { Yield }\end{array}$ & C & H & N & S & O* & HHV & $\begin{array}{l}\text { Energy } \\
\text { recovery }\end{array}$ & $\begin{array}{l}\text { Ash } \\
\text { content }\end{array}$ \\
\hline No catalyst & $14.6 \pm 0.4$ & $70.31 \pm 0.3$ & $11.03 \pm 0.4$ & $7.04 \pm 0.3$ & $1.07 \pm 0.1$ & 10.24 & 23.34 & 36.05 & $6.1 \pm 0.1$ \\
\hline $\mathrm{Na}_{2} \mathrm{CO}_{3}$ & $20.1 \pm 0.3$ & $74.83 \pm 0.5$ & $12.01 \pm 0.3$ & $5.01 \pm 0.1$ & $0.93 \pm 0.3$ & 7.03 & 25.59 & 54.42 & $4.5 \pm 0.1$ \\
\hline $\mathrm{TiO}_{2}$ & $18.74 \pm 0.4$ & $72.45 \pm 0.3$ & $9.03 \pm 0.5$ & $8.62 \pm 0.1$ & $0.78 \pm 0.2$ & 8.01 & 25.37 & 50.31 & $5.7 \pm 0.1$ \\
\hline $\mathrm{CaO}$ & $17.37 \pm 0.1$ & $71.91 \pm 0.3$ & $8.02 \pm 0.2$ & $9.66 \pm 0.2$ & $1.15 \pm 0.2$ & 7.62 & 23.80 & 43.74 & $5.1 \pm 0.1$ \\
\hline
\end{tabular}

Table 3. Properties of biocrude-oil with and without catalyst (wt.\% in dry basis). *By difference.

\begin{tabular}{|l|c|c|c|c|}
\hline Parameter & $\begin{array}{l}\text { Aqueous phase } \\
\text { without catalyst }\end{array}$ & $\begin{array}{l}\text { Aqueous phase } \\
\text { with } \mathbf{C a O}\end{array}$ & $\begin{array}{l}\text { Aqueous phase } \\
\text { with } \mathrm{TiO}_{2}\end{array}$ & $\begin{array}{l}\text { Aqueous phase } \\
\text { with } \mathbf{N a}_{2} \mathbf{C O}_{3}\end{array}$ \\
\hline $\mathrm{pH}$ & 7.9 & 7.5 & 7.8 & 8.3 \\
\hline $\mathrm{COD}\left(\mathrm{mg} \mathrm{L}^{-1}\right)$ & $25492 \pm 05$ & $36025 \pm 02$ & $32472 \pm 05$ & $40391 \pm 04$ \\
\hline $\mathrm{TN}\left(\mathrm{mg} \mathrm{L}^{-1}\right)$ & $1491 \pm 02$ & $1503 \pm 01$ & $1646 \pm 03$ & $1805 \pm 05$ \\
\hline $\mathrm{TP}\left(\mathrm{mg} \mathrm{L}^{-1}\right)$ & $904 \pm 04$ & $1034 \pm 02$ & $876 \pm 03$ & $1023 \pm 01$ \\
\hline TOC $\left(\mathrm{mg} \mathrm{L}^{-1}\right)$ & $13540 \pm 01$ & $16738 \pm 05$ & $20621 \pm 02$ & $19645 \pm 04$ \\
\hline
\end{tabular}

Table 4. Chemical characteristics of HTL aqueous phase.

Phytol) were also recorded during the study. This may be due to differences in algal species, composition of the macroalgal blooms and also different GC-MS analysis procedure implemented.

HHV and ER of algal blooms biocrude oil. The primary elements present in biocrude oils obtained by the catalytic and non-catalytic reaction is given in Table 3 . The biocrude oil extracted in the absence of catalyst displayed higher carbon content (70.31\%) rather than the macroalgal blooms.

Element enrichment percentage was higher in biocrude oil obtained using $\mathrm{Na}_{2} \mathrm{CO}_{3}$ as a catalyst In the biocrude oil, the nitrogen concentration was less as compared to the green algae. This may be a result of nitrogenous compounds that are obtained in the liquid phase of the HTL process. The amount of nitrogen in the biomass of macroalgal blooms is higher than that of bio-crude oil as a result of generation of nitrogenous compounds during the HTL process in aqueous phase ${ }^{21}$. In contrast to our study, Ross et al. ${ }^{12}$ reported that using $\mathrm{Na}_{2} \mathrm{CO}_{3}$ there is an increase in nitrogen content, whereas Jena et al. ${ }^{20}$ observed a decrease in nitrogen content of biocrude oil with $\mathrm{Na}_{2} \mathrm{CO}_{3}$ catalyst. The sulfur content was recorded below one wt. $\%$ for $\mathrm{Na}_{2} \mathrm{CO}_{3}$ and $\mathrm{TiO}_{2}$ based reaction, whereas for petroleum crude oil, it varies between 0 and three wt. $\%{ }^{22}$.

$\mathrm{HHV}$ of the biocrude oil was obtained with $\mathrm{Na}_{2} \mathrm{CO}_{3}\left(25.59 \mathrm{MJ} \mathrm{kg}^{-1}\right)$ followed by $\mathrm{TiO}_{2}\left(25.37 \mathrm{MJ} \mathrm{kg} \mathrm{kg}^{-1}\right)$ and $\mathrm{CaO}$ $\left(23.80 \mathrm{MJ} \mathrm{kg}^{-1}\right)$. These values are higher as compared to HHV of macroalgal blooms $\left(9.45 \mathrm{MJ} \mathrm{kg}^{-1}\right)$.

Analysis of HTL water phase. Water phase obtained by the HTL of harmful macroalgal blooms had a very foul smell and is dark brown. The $\mathrm{pH}$ of catalytic reactions (7.8-8.3) was found to be higher than non-catalytic reaction (7.6) (Table 4). The same pattern of $\mathrm{pH}$ was also observed in the aqueous phase of other algal biomass after HTL when $\mathrm{Na}_{2} \mathrm{CO}_{3}$ was used as catalyst ${ }^{12,22}$.

The high amount of TOC present in the liquid phase of HTL is due to organic matter of feedstock dissolved in water. The nitrogen content in the HTL liquid phase increases in catalyzed reaction because algal proteins get converted into water-soluble amino acids and ammonia ${ }^{23}$.

Effect of catalysts stress on microalgal growth, biomass and lipid productivity. Microalgal growth in the aqueous phase of each catalyst is different; it may be due to removal and detoxification of catalyst by adsorption of catalysts on to the cell surface or intracellular metabolism of microalgae in response to catalysts. In the aqueous phase of $\mathrm{Na}_{2} \mathrm{CO}_{3}$ and $\mathrm{TiO}_{2} \log$ phase lasted from day 6 to day 24 . While in the aqueous phase of the $\mathrm{CaO} \log$ phase lasted from day 5 to day 20 (Fig. 2). Overall microalgae, biomass productivity (g/l) after the stationary phase in the control medium (BBM) was found to decrease as compared to the HTL aqueous phase. As Fig. 2 shown that microalgae cultivated in HTL grew with the slow rate but the linear fashion after four days. Each catalyst affects the biomass and lipid productivity differently. Highest lipid yield and productivity of $32 \pm 6.1 \%$ and $147 \pm 1.3 \mathrm{mg} \mathrm{L}^{-1} \mathrm{~d}^{-1}$ were recorded in Scenedesmus abundansgrown in aqueous phase containing catalyst $\mathrm{TiO}_{2}$ followed by $\mathrm{CaO}$ (Chorella minutissima $26.4 \pm 1.7 \% ; 157 \pm 1.2 \mathrm{mg} \mathrm{L}^{-1} \mathrm{~d}^{-1}$ ), $\mathrm{Na}_{2} \mathrm{CO}_{3}$ (Scenedesmus abundans $24.2 \pm 2.1 \% ; 110 \pm 1.5 \mathrm{mg} \mathrm{L}^{-1} \mathrm{~d}^{-1}$ ), and control (Chorella minutissima $22.16 \pm 1.6 \% ; 134 \pm 2.1 \mathrm{mg} \mathrm{L}^{-1} \mathrm{~d}^{-1}$ ) (Tables 5 and 6).

\section{Discussion}

FTIR spectrum of harmful macroalgal blooms reflects three central regions, lipid band (around $1630 \mathrm{~cm}^{-1}$ ), amide band $\left(1401 \mathrm{~cm}^{-1}\right)$ and the carbohydrate region $\left(1100-874 \mathrm{~cm}^{-1}\right)$. Peaks between $2516-1401 \mathrm{~cm}^{-1}$ presents the lipid and phenolic content of algal blooms ${ }^{24}$. Higher phenolic content was reported in marine macroalgae ${ }^{25}$. The sharp peak at $1639 \mathrm{~cm}^{-1}$ is $\mathrm{C}=\mathrm{O}$ amide stretching of proteins present in algae $\mathrm{e}^{26}$.

In the present study, for the first time harmful macroalgal blooms were used in HTL process for biocrude oil production. High-temperature $\left(300-500^{\circ} \mathrm{C}\right.$ with holding time of $30-60 \mathrm{~min}$ ) based HTL process for the conversion of biomass to bio-crude oil have been reported in previous studies ${ }^{27,28}$. However, the low-temperature 


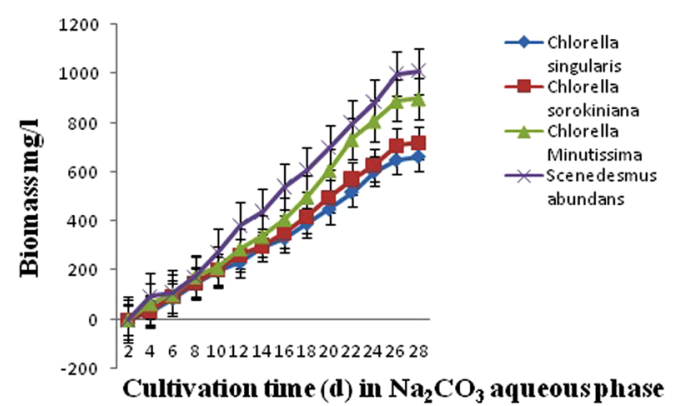

A

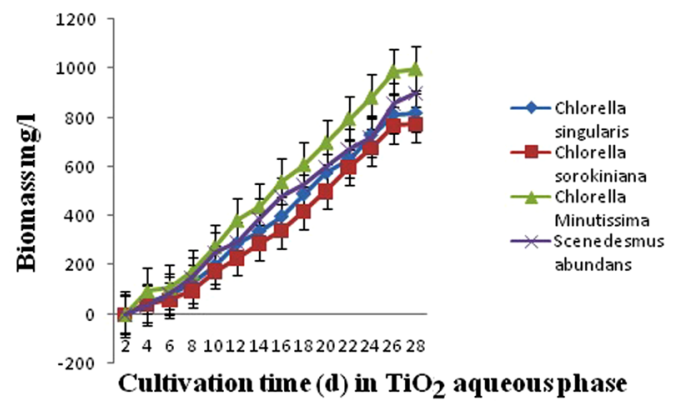

C

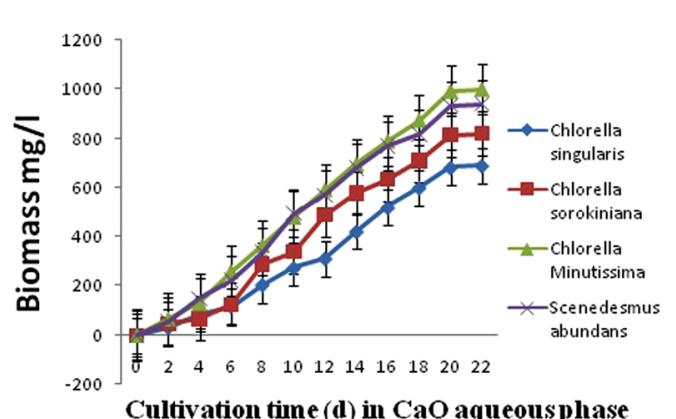

B

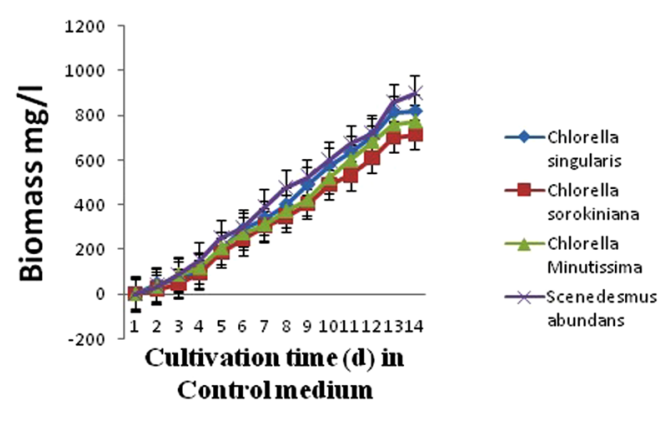

D

Figure 2. Effect of different catalyst (A-C) and control medium (D) on the growth of microalgae strains.

\begin{tabular}{|l|l|l|l|l|l|l|l|l|}
\hline \multirow{2}{*}{$\begin{array}{l}\text { Aqueous } \\
\text { phase }\end{array}$} & \multicolumn{3}{|l|}{ Scenedesmus abundans } & \multicolumn{2}{l|}{ Chorella minutissima } & \multicolumn{2}{l|}{ Chlorella sorokiniana } & \multicolumn{2}{l|}{ Chlorella singularis } \\
\cline { 2 - 9 } & $\begin{array}{l}\text { Biomass } \\
\mathbf{m g} / \mathbf{l}\end{array}$ & Lipid \% & $\begin{array}{l}\text { Biomass } \\
\mathbf{m g} / \mathbf{l}\end{array}$ & Lipid \% & $\begin{array}{l}\text { Biomass } \\
\mathbf{m g} / \mathbf{l}\end{array}$ & Lipid \% & $\begin{array}{l}\text { Biomass } \\
\mathbf{m g} / \mathbf{l}\end{array}$ & Lipid \% \\
\hline $\mathrm{CaO}$ & $1007 \pm 0.5$ & $22.2 \pm 0.1$ & $1012 \pm 0.1$ & $26.4 \pm 1.7$ & $820 \pm 0.2$ & $23 \pm 4.1$ & $690 \pm 0.5$ & $20 \pm 4.1$ \\
\hline $\mathrm{TiO}_{2}$ & $958 \pm 0.1$ & $32 \pm 6.1$ & $1003 \pm 0.5$ & $28 \pm 1.1$ & $768 \pm 0.1$ & $26 \pm 2.1$ & $835 \pm 0.3$ & $23.2 \pm 3.4$ \\
\hline $\mathrm{Na}_{2} \mathrm{CO}_{3}$ & $986 \pm 0.2$ & $24.2 \pm 2.1$ & $900 \pm 0.2$ & $21 \pm 3.2$ & $732 \pm 0.2$ & $22.5 \pm 1.1$ & $664 \pm 0.1$ & $22 \pm 1.1$ \\
\hline Control & $992 \pm 0.4$ & $21 \pm 6.1$ & $774 \pm 0.2$ & $22.16 \pm 1.6$ & $713 \pm 0.2$ & $21 \pm 3.2$ & $826 \pm 0.1$ & $19.2 \pm 0.2$ \\
\hline
\end{tabular}

Table 5. Lipid and algal biomass productivity with different aqueous phase at concentration $400 \times+1 \% \mathrm{BBM}$.

\begin{tabular}{|l|l|l|l|l|l|}
\hline Microalgae & $\mathbf{2 0 0 \times}$ & $\mathbf{4 0 0 \times}$ & $\begin{array}{l}\mathbf{4 0 0} \times+\mathbf{1} \% \\
\text { BBM }\end{array}$ & $\mathbf{6 0 0 \times}$ & BBM \\
\hline Scenedesmus abundans & $106 \pm 02$ & $759 \pm 02$ & $945 \pm 02$ & No growth & $900 \pm 01$ \\
\hline Chorella minutissima & $204 \pm 02$ & $648 \pm 01$ & $803 \pm 02$ & $107 \pm 03$ & $774 \pm 01$ \\
\hline Chlorella sorokiniana & $67 \pm 01$ & $589 \pm 02$ & $741 \pm 01$ & No growth & $713 \pm 02$ \\
\hline Chlorella singularis & No growth & $461 \pm 04$ & $798 \pm 03$ & $245 \pm 03$ & $820 \pm 01$ \\
\hline
\end{tabular}

Table 6. Dry weights of microalgae cultivated in different dilutions of aqueous phase of HTL of harmful algal blooms and in BBM (mg/l).

(250-290) HTL process is still in the trial stage. In this study maximum, $20.1 \pm 0.3 \%$ oil was obtained in the presence of catalyst $\mathrm{Na}_{2} \mathrm{CO}_{3}$ at $270{ }^{\circ} \mathrm{C}$ for $45 \mathrm{~min}$.

The presence of catalysts showed the increase in oil yield and decrease in the biochar formation ${ }^{29}$. Catalysts increase the quality of biocrude oil by two ways (a) Introduction of catalysts at the time of the HTL process. (b) Upgrade the bio-oil quality after HTL. Catalysts from renewable resources are getting attention because they reduce the production cost of biofuels ${ }^{30}$. In this study, eggshell were used to produced $\mathrm{CaO}$ catalyst. Use of $\mathrm{Na}_{2} \mathrm{CO}_{3}$ as a catalyst in HTL leads to increases in the yield of biocrude oil from algal blooms. The bio-oil produced with $\mathrm{Na}_{2} \mathrm{CO}_{3}$ also had high heating value. Yeh et al. ${ }^{31}$ reported that $\mathrm{Na}_{2} \mathrm{CO}_{3}$ increases the yield ofbiocrude oil during the HTL of algal biomass containing a high content of carbohydrates by converting it into the oil.

In this study maximum yield of crude oil $(20.10 \%)$ was reported with catalyst $\mathrm{Na}_{2} \mathrm{CO}$. The presence of $\mathrm{Na}_{2} \mathrm{CO}_{3}$ catalyst has mainly suited the conversion of carbohydrates into biocrude oil in macroalgae and plant-based 
biomass ${ }^{12,23}$. However, $\mathrm{Na}_{2} \mathrm{CO}_{3}$ is inimical to the conversion of algal lipids to biocrude oil and not suitable for algal species contain high lipid contents ${ }^{23}$. Shakya et al..$^{22}$ reported that higher amount of carbohydrates containing microalgae species led to increasing in bio-oil yield when $\mathrm{Na}_{2} \mathrm{CO}_{3}$ is used as a catalyst. In this study, $\mathrm{HHV}$ and ER value of algal blooms biocrude oil with catalyst $\mathrm{Na}_{2} \mathrm{CO}_{3}$ were $25.59 \mathrm{MJ} / \mathrm{Kg}$ and $27.50 \%$ respectively. At similar pressure, Alhassan et al..$^{32}$ reported the $21.15 \pm 0.82 \mathrm{MJ} / \mathrm{kg}$ and ER $41.48 \%$ of biocrude oil of Jatropha curcas cake under $250^{\circ} \mathrm{C}$ temperature. The energy efficiency of HTL biocrude oil depends on the HHV ${ }^{33}$.

Many catalysts such as $\mathrm{KOH}, \mathrm{NaOH}, \mathrm{CH}_{3} \mathrm{COOH}$, and $\mathrm{H}_{2} \mathrm{SO}_{4}$ have been used by various researchers in $\mathrm{HTL}$ of microalgae, and these catalysts can also be reused as growth media for the growth of microalgae along with aqueous phase ${ }^{12,21}$. Wang et al. ${ }^{27}$ reported that by using $\mathrm{TiO}_{2}$ in $\mathrm{HTL}$ of microalgae at $300^{\circ} \mathrm{C}$ leads to the highest bio-oil yield and the maximum liquefaction conversion.

The higher organic carbon content of macroalgae was responsible for the higher yield of bio oil ${ }^{34}$. The crude oil obtained from this study was $14-20 \% \mathrm{dw}$ which is more similar to as reported in different green macroalgal species, Enteromorpha prolifera $23.0 \%{ }^{16}$, Oedogonium $26.2 \%$ and Ulva $18.7 \%$ of dry weight ${ }^{34}$.

Algal biomass protein first to gets converted into amino acids and finally into amines and amides by HTL process $^{12}$. Ketones and phenols produced during HTL were obtained from carbohydrates by hydrolysis and dehydration process. The lipids were responsible for the generation of alkenes ${ }^{16}$. Change in nitrogen concentration of aqueous phase of HTL depends on the temperature, type of catalyst, and algae strain ${ }^{12,22}$. High nitrogen content was reported in this study with $\mathrm{Na}_{2} \mathrm{CO}_{3}$ as a catalyst. Similar results were observed by Shakya et al. ${ }^{22}$, when $\mathrm{Na}_{2} \mathrm{CO}_{3}$ used as a catalyst in HTL of Isochrysis and Pavlova at low temperature, as $\mathrm{Na}_{2} \mathrm{CO}_{3}$ increased hydrolysis of protein into water-soluble compounds.

The aqueous phase of HTL had a high amount of soluble organic compound, carbon, and nitrogen. Kumar et $a l .{ }^{35}$ reported that $\mathrm{CaCl}_{2}$ increases microalgal biomass productivity. High lipid content was reported in catalysts containing aqueous phase as compared to control. These results were in congruence with other studies in which an increase in lipid content on exposure to heavy metals was reported ${ }^{36}$. Oxidative stress results in degradation of the photosynthetic machinery, while the protective mechanism of algal cells leads to the accumulation of unsaturated fatty acids ${ }^{37}$.

This experimental work confirmed that harmful macroalgal blooms are a suitable feedstock for HTL and aqueous phase can be reuse as a nutrient source for cultivation of microalgal biomass.

\section{Material and Methods}

Materials. Microalgae strains Chorella minutissima (MCC-27), Scenedesmus abundans (NCIM 2897), Chlorella singulari UUIND, and Chlorella sorokiniana UUIND6 were used in present study. All the chemicals, including $\mathrm{TiO}_{2}$ and $\mathrm{Na}_{2} \mathrm{CO}_{3}$ and solvents used, were HPLC grade and acquired from Himedia, India.

Proximate analysis of green macroalgal blooms. Green macroalgal blooms were locally collected during the winter season (December-February 2017) from water pond, and freshwater river nearby Uttaranchal University, Uttarakhand, India. The ash content of algal blooms biomass was determined according to the NREL Analytical Procedure ${ }^{38}$. Elemental compositions of algal blooms were determined by the elemental analyzer (Thermo Fisher, USA). The proximate analysis of the sample was carried out using the standard methods given by the Association of Official Analytical Chemists (AOAC). FTIR analysis (FTIR 6700, NICOLET) of algal blooms biomass frequency range $4000-450 \mathrm{~cm}^{-1}$ were used.

Experimental procedure of hydrothermal liquefaction (HTL). The Hydrothermal liquefaction (HTL) of harmful macroalgal blooms was carried out in a $100 \mathrm{ml}$ high-pressure autoclave (Parr reactor) operated in a batch mode. Different types of catalysts in different concentrations were used in HTL process reported in the literature, but 10:1 (feedstock: catalyst) ratio has been reported to give the maximum conversion rate of feedstock to crude oil by $\mathrm{HTL}^{27,39}$. The reactor was loaded with wet algal blooms with/without catalyst in 10:1 ratio. Three types of catalysts were used in this study viz; $\mathrm{TiO}_{2}, \mathrm{Na}_{2} \mathrm{CO}_{3}$, and $\mathrm{CaO}$. The $\mathrm{CaO}$ catalyst was prepared from eggshells according to the protocol given by Niju et al..$^{40}$. The reactor was heated up to $270^{\circ} \mathrm{C}$ and pressure $4.5 \mathrm{MPa}$ with $\mathrm{He}$ gas, a heating rate of $5^{\circ} \mathrm{C} / \mathrm{min}$ for holding time of $45 \mathrm{~min}$. After the completion of reaction, the reactor was immediately cooled and opened; gas was vented off, water phase and solid mixture were separated from each other by vacuum filtration. The filtrate was marked as an aqueous phase which consists of dissolved organic compounds. Two separation methods were used for recovering these products.

In the first separation method, the solid phase was treated with acetone three times to recover the oil phase. Acetone was evaporated at $60^{\circ} \mathrm{C}$, and the resulting oil phase was weighed and marked as Biocrude oil 1. The water phase was treated with diethyl ether. Aspirating out upper phase and diethyl ether was evaporated in a rotary evaporator. The total biocrude oil obtained was measured gravimetrically and marked as biocrude oil 2.

In the second separation, Karagoz et al. ${ }^{29}$ method were used with some modificationa, briefly the solid phase was acidified to $\mathrm{pH} 1-2$ with $\mathrm{H}_{2} \mathrm{SO}_{4}(1.3 \mathrm{M})$ overnight and dried next day. Biocrude oil from the solid mixture was extracted using soxhlet extraction apparatus with acetone as solvent until the solvent in the thimble becomes colorless. Allowed to stand for three h, upper pahse was separated out. The lower phase (pallets) contain catalyst or residues of catalyst. Acetone was recovered from the upper phase at $60^{\circ} \mathrm{C}$. The extracted oil phase was weighed and marked as biocrude oil-1. Diethyl ether was added to liquid phase and aspirating out upper phase and evaporated diethyl ether in a rotary evaporator and remaining fraction was measured gravimetrically and marked as biocrude oil- 2 .

Biocrude oil- 1 was mixed with biocrude oil- 2 for the calculation of \%wt of total biocrude oil. Analysis of biocrude samples was doen using an elemental analyzer (Thermo Fisher, USA). 
HHV and energy recovery (ER). The essential properties of HTL biocrude oil such as biocrude oil yield percentage, HHV, element enrichment \%, and ER were calculated using the empirical formulas given below ${ }^{27,41}$.

$$
\begin{aligned}
& \text { Biocrude oil }(w t \%)=\text { Biocrude oil/algal biomass } \times 100 \\
& H H V\left(M J \mathrm{~kg}^{-1}\right)=0.3383 \times \mathrm{C}+1.442 \times(\mathrm{H}-\mathrm{O} / 8) \\
& \text { ER }(\%)=\frac{\text { Yield of biocrude oil } \% \times H H V \text { biocrude oil } \%}{H H V \text { feedstock }}
\end{aligned}
$$

Aqueous phase water quality analysis. Aqueous phase quality analysis was done to estimate (TN), i.e., Total Nitrogen $\left(\mathrm{NO}_{3}^{-}, \mathrm{NO}_{2}^{-} \& \mathrm{NH}_{4}{ }^{+}\right)$and (TP) Total phosphorus $\left(\mathrm{PO}_{4}^{-}\right)$. HACH DR 5000 analyzer was used to measure Total Chemical Oxygen (COD) demand. The Total Organic Carbon (TOC) was analyzed by a TOC analyzer (Shimadzu TOC-V).

Cultivation of microalgae on the aqueous phase. Four microalgal strains Chlorella Minutissima, Chlorella sorokiniana UUIND6, Chlorella singularis UUIND5, and Scenedesmus abundans were used in this study.

Scenedesmus abundans wasprocured from NCIM, Pune, India. Chlorella Minutissima was procured from IARI, New Delhi, India. Chlorella singularis UUIND5 and Chlorella sorokiniana UUIND6 were earlier isolated by our group.

Microalgal strains were cultivated in $1 \mathrm{~L}$ shake flasks containing different dilutions of the aqueous phase of catalytic and non-catalytic reaction and Bold's Basal Medium (BBM) as a control for 14 days with $16 \mathrm{~h}$ light: $8 \mathrm{~h}$ dark photoperiod and irradiated with LED tubes $\left(200 \mu \mathrm{mol} \mathrm{m}^{-2} \mathrm{~s}^{-1}\right)$. BBM was prepared according to the protocol developed by Guarnieri et al. ${ }^{42}$.

Three concentrations $200 \times, 400 \times$ and $600 \times$ of the aqueous phase of non-catalytic reaction were prepared by the dilution of distilled water (Table 1). The effect on the growth rate of microalgae strains was observed by taking absorbance at $750 \mathrm{~nm}$ using UV-Vis spectrophotometer (Shimadzu 133 model no. 1700). Dilution $400 \times$ was capable of growing the maximum biomass and was further evaluated for their efficiency in biomass production with $1 \%$ BBM and $400 \times$ dilution of the aqueous phase of the catalytic reaction.

Determination of total lipid content $(\%, w / w)$ and lipid productivity of the cultivated microalgae. For extraction of lipids, first of all, samples were dried from the $\% \mathrm{ml}$ culture broth. Further, the microalgal cells were broken down using liquid nitrogen with the help of a mortar and pestle. The fine powder was obtained from which the lipids were extracted using chloroform:methanol (2:1) kept overnight at room temperature, with constant shaking ${ }^{35}$. The extract obtained was treated with $0.034 \% \mathrm{MgCl}_{2}$, centrifuged at $3500 \mathrm{rpm}$ for $5 \mathrm{~min}$. The supernatant was washed two-three times with $1 \mathrm{ml}$ of $2 \mathrm{~N} \mathrm{KCl} / \mathrm{methanol}(4: 1 \mathrm{v} / \mathrm{v}) .5 \mathrm{ml}$ of chloroform/methanol/ water $(3: 48: 47, \mathrm{v} / \mathrm{v} / \mathrm{v})$ was added to it. The bottom chloroform layer was transferred to a new test tube, and lipids yield was measured gravimetrically. Lipid production and percentage of lipid were calculated by the following equations ${ }^{35}$ :

$$
\begin{aligned}
& \text { Lipid yield } \%=\text { Lipid content }(\mathrm{g}) / \text { Dry algae biomass }(\mathrm{g}) \times 100 \\
& \text { Lipid productivity }=\text { Biomass productivity } \times \text { Lipid yield }(\%) / 100
\end{aligned}
$$

Statistical analysis. All the experiments were done in triplicates $(n=3)$ and are presented in mean value \pm SD. A GraphPad Prism software (version7:0) with $\mathrm{p}<0.05$ was used in this study.

\section{References}

1. Valiela, I. et al. Macroalgal blooms in shallow estuaries: Controls and ecophysiological and ecosystem consequences. Limnology and Oceanography. 42, 1105-1118 (1997).

2. Sfriso, A., Marcomini, A. \& Pavoni, B. Relationships between macroalgal biomass and nutrient concentrations in a hypertrophic area of the Venice Lagoon Italy. Marine Environmental Research. 22, 297-312 (1987).

3. Edgar, G. J., Barrett, N. S., Graddon, D. J. \& Last, P. R. The conservation significance of estuaries: A classification of Tasmanian estuaries using ecological, physical, and demographic attributes as a case study. Biological Conservation. 92, 383-397 (2000).

4. Jones, M. \& Pinn, E. The impact of a macroalgal mat on benthic biodiversity in Poole Harbour. Mar Poll Bull. 53(1-4), 63-71 (2006).

5. Van Dolah, F. M., Fire, S. E., Leighfield, T. A., Mikulski, T. A. \& Doucette, G. L. Determination of paralytic shellfish toxins in shellfish by receptor binding assay: a collaborative study. Journal of AOAC International. 95, 795-812 (2012).

6. Brennan, L. \& Owende, P. Biofuels from microalgae; A review of technologies for production, processing, and extractions of biofuels and co-products. Renewable Sustainable Energy Rev. 14, 557-577 (2010).

7. Jain, P., Arora, N., Mehtani, J., Pruthi, V. \& Majumder, C. B. Pretreated algal bloom as a substantial nutrient source for microalgae cultivation for biodiesel production. Bioresource Technology. 242. 152-160 (2017).

8. Yu, G., Zhang, Y., Schideman, L., Funk, T. L. \& Wang, Z. Hydrothermal liquefaction of low lipid content microalgae into bio-crude oil. Transactions of the ASABE. 54(1), 239-246 (2011).

9. Peterson, A., Vogel, F., Lachance, R., Froeling, M. \& Antal, M. Thermochemical biofuel production in hydrothermal media: A review of sub- and supercritical water technologies. Energy Environ. Sci. 1, 32-65 (2008).

10. Vardon, D. R., Sharma, B. K., Blazina, G. V., Rajagopalan, K. \& Strathmann, T. J. Thermo- the chemical conversion of raw and defatted algal biomass via hydrothermal liquefaction and slow pyrolysis. Bioresour Technol. 109, 178-87 (2012).

11. Guo, Y., Thomas, Y., Wenhan, S., Dongha, iX. \& Shuzhong, W. A review of bio-oil production from hydrothermal liquefaction of algae. Renewable and Sustainable Energy Reviews. 48, 776-790 (2015).

12. Ross, A. B. et al. Hydrothermal processing of microalgae using alkali and organic acids. Fuel. 89, 2234-2243 (2010). 
13. Cole, A. et al. From Macroalgae to Liquid Fuel via Waste-Water Remediation, Hydrothermal Upgrading, Carbon Dioxide Hydrogenation, and Hydrotreating. Energy Environ. Sci., https://doi.org/10.1039/C6EE00414H (2016).

14. Demirbaş, A. Thermochemical conversion of biomass to liquid products in the aqueous medium. Energy Source. 27, 1235-1243 (2005).

15. Kumar, K. et al. Recent developments on biofuels production from microalgae and macroalgae. Renew Sustain Energy Rev. 65 , 235-49 (2016)

16. Zhou, D., Zhang, L., Zhang, S., Fu, H. \& Chen, J. Hydrothermal liquefaction of macroalgae Enteromor phaprolifera to bio-oil. Energy Fuel. 24, 4054-4061 (2010).

17. Slade, R. \& Bauen, A. Micro-algae cultivation for biofuels: Cost, energy balance, environmental impacts, and prospects. Biomass and Bioenergy. 53, 29-38 (2013).

18. Arun, J., Varshini, P., Prithvinath, P. K., Priyadarshini, V. \& Gopinath, K. P. Enrichment of bio-oil after hydrothermal liquefaction (HTL) of microalgae C. vulgaris grown in wastewater: Bio-char and post HTL wastewater utilization studies. Bioresource Technology. 261, 182-187 (2018).

19. Zhou, Y., Schideman, L., Yu, G. \& Zhang, Y. A synergistic combination of algal wastewater treatment and hydrothermal biofuel production maximized by nutrient and carbon recycling. Energy Environ. Sci. 6, 3765-3779 (2013).

20. Jena, U., Das, K. C. \& Kastner, J. R. Comparison of the effects of $\mathrm{Na}_{2} \mathrm{CO}_{3}, \mathrm{Ca}_{3}\left(\mathrm{PO}_{4}\right)_{2}$, and $\mathrm{NiO}$ catalysts on the thermochemical liquefaction of microalga Spirulina platensisAppl. Energy. 98, 368-375 (2012).

21. Muppaneni, H. K. et al. Hydrothermal liquefaction of Cyanidioschyzonmerolae and the influence of catalysts on products. Bioresour. Technol. 223, 91-97 (2017).

22. Shakya, R. et al. Effect of temperature and $\mathrm{Na} 2 \mathrm{CO} 3$ catalyst on hydrothermal liquefaction of algae. Algal Research. 12, 80-90 (2015).

23. Biller, P. \& Ross, A. B. Potential yields and properties of oil from the hydrothermal liquefaction of microalgae with different biochemical content. Bioresour. Technol. 102, 215-225 (2011).

24. Chingombe, P., Saha, B. \& Wakeman, R. J. Surface modification and characterization of coal-based activated carbon. Carbon 43, 3132-43 (2005).

25. Alberto, M. R., Faryas, M. E. \& Manca de Nadra, M. C. Effect of gallic acid, and catechin on Lactobacillus hilgardii growth and metabolism of organic compounds. J. Agric. Food Chem. 49, 4359-4363 (2001).

26. Mahapatra, D. M. \& Ramachandra, T. V. Algal biofuel: bountiful lipid from Chlorococcum sp. proliferating in municipal wastewater. Curr Sci 105, 47-55 (2013).

27. Wang, W. et al. Hydrothermal liquefaction of microalgae over transition metal supported $\mathrm{TiO}_{2}$ catalyst. Bioresource Technology. 250, 474-480 (2018)

28. Qian, L., Wang, S. \& Savage, P. E. Hydrothermal liquefaction of sewage sludge under isothermal and fast Conditions. Bioresour. Technol. 232, 27-34 (2017).

29. Karagoz, S., Bhaskar, T., Muto, A., Sakata, Y. \& Uddin, M. A. Low-temperature hydrothermal treatment of biomass: effect of reaction parameters on products and boiling point distributions. Energy Fuels. 18(1), 234-241 (2004)

30. Abdullah, S. H. Y. S. et al. A review of biomass-derived heterogeneous catalyst for sustainable biodiesel production. Renew Sust Energy Rev 70, 1040-51 (2017).

31. Yeh, T. M. et al. Hydrothermal catalytic production of fuels and chemicals from aquatic biomass. J. Chem. Technol. Biotechnol. 88, 13-24 (2013).

32. Alhassan, Y., Kumar, N. \& Bugaje, I. M. Hydrothermal liquefaction of de-oiled Jatropha curcas cake using Deep Eutectic Solvents (DESs) as catalysts and co-solvents. Bioresour Technol 199, 375-381 (2016).

33. Schaschke, C. A. Dictionary of Chemical Engineering; Oxford University Press: Oxford, UK (2014).

34. Neveux, N. et al. Biocrude yield and productivity from the hydrothermal liquefaction of marine and freshwater green macroalgae. Bioresource Technology. 155, 334-341 (2014).

35. Kumar, V., Kumar, R., Rawat, D. \& Nanda, M. Synergistic dynamics of light, photoperiod and chemical stimulants influence biomass and lipid productivity in Chlorella singularis (UUIND5) for biodiesel production. Appl Biol Chem. 61, 7-13 (2018).

36. Yang, J., Cao, J., Xing, G. \& Yuan, H. Lipid production combined with biosorption and bioaccumulation of cadmium, copper, manganese, and zinc by oleaginous microalgae Chlorella minutissima UTEX2341. Bioresour. Technol. 175, 537-544 (2015).

37. Zhang, Y. M., Chen, H., He, C. L. \& Wang, Q. Nitrogen starvation induced oxidative stress in an oil-producing green alga Chlorella sorokiniana C3. PLoS One 8, 1-12 (2013).

38. Sluiter, A. Determination of ash in biomass. NREL Biomass Analysis Technology Team Laboratory Analytical Procedure \#005. NREL, Golden, CO; online at, http://www.nrel.gov/biomass/analytical_procedures.html\#lap-005 (2005).

39. Zhu, Z., Rosendahl, L., Toor, S. S., Yu, D. \& Chen, G. Hydrothermal liquefaction of barley straw to bio-crude oil: Effects of reaction temperature and aqueous phase recirculation. Applied Energy 137, 183-192 (2015).

40. Niju, S., Meera, K. M., Begum, S. \& Anantharaman, N. Modification of eggshell and its application in biodiesel production. Journal of Saudi Chemical Society. 18, 702-706 (2014).

41. Channiwala, S. A. \& Parikh, P. P. A unified correlation for estimating HHV of solid, liquid, and gaseous fuels. Fuel. 81(8), 1051-1063 (2002).

42. Guarnieri, M. T., Nag, A., Yang, S. \& Pienkos, P. T. Proteomic analysis of Chlorella vulgaris: potential targets for enhanced lipid accumulation. J Proteome. 93, 245-253 (2013).

\section{Author Contributions}

Conception and design of the study by Vinod Kumar, Mikhail S. Vlaskin and Manisha Nanda. Drafting and Analysis, interpretation of the data by Sanjay Kumar, Monu Verma, P.K. Chauhan, Harish Chandra Joshi, Waseem Ahmad, Vivekanand Bahuguna, Poonam Negi, Nishesh Sharma, Bharti Ramola, Indra Rautela.

\section{Additional Information}

Supplementary information accompanies this paper at https://doi.org/10.1038/s41598-019-47664-w.

Competing Interests: The authors declare no competing interests.

Publisher's note: Springer Nature remains neutral with regard to jurisdictional claims in published maps and institutional affiliations. 
(c) (i) Open Access This article is licensed under a Creative Commons Attribution 4.0 International License, which permits use, sharing, adaptation, distribution and reproduction in any medium or format, as long as you give appropriate credit to the original author(s) and the source, provide a link to the Creative Commons license, and indicate if changes were made. The images or other third party material in this article are included in the article's Creative Commons license, unless indicated otherwise in a credit line to the material. If material is not included in the article's Creative Commons license and your intended use is not permitted by statutory regulation or exceeds the permitted use, you will need to obtain permission directly from the copyright holder. To view a copy of this license, visit http://creativecommons.org/licenses/by/4.0/.

(C) The Author(s) 2019 